\title{
A cukorbetegség szemészeti szövődményeinek modellalapú költségterhe Magyarországon
}

\author{
Tóth Gábor dr. - Nagy Zoltán Zsolt dr. - Németh János dr. \\ Semmelweis Egyetem, Általános Orvostudományi Kar, Szemészeti Klinika, Budapest
}

\begin{abstract}
Bevezetés: A diabeteses retinopathia minden harmadik cukorbeteget érinti a világban, és a dolgozó korú lakosság körében a vakság vezető oka.

Célkitüzés: Tanulmányunk célja a diabeteses retinopathia prevalenciaalapú költségterhének meghatározása 2018-ban a 18 évnél idősebb korú lakosság körében Magyarországon.

Módszer: Standardizált 'rapid assessment of avoidable blindness' (RAAB) + diabeteses retinopathia modul alapú metodikán alapuló modellel analizáltuk a diabeteses retinopathia költségterhét. A diabeteses retinopathia okozta gazdasági terhet a Nemzeti Egészségbiztosítási Alapkezelő és a páciensek oldaláról felmerülő költségeket analizálva vizsgáltuk. A prevalenciaalapú diabeteses retinopathia költségmodellt a skót diabeteses retinopathia klasszifikációnak és a diabeteses retinopathia súlyossági stádiumának megfelelően állítottuk össze.

Eredmények: A diabeteses retinopathia költségterhe 43,66 milliárd Ft volt 2018-ban. A két fö költségviselő az antiVEGF-injekciók (28,91 milliárd Ft) és a vitrectomiák (8,09 milliárd Ft) voltak. Ez a két kezelési mód volt felelős a diabeteses retinopathiával kapcsolatban felmerülő összes költség 84,7\%-áért. Az egy páciensre jutó átlagos költségteher 54691 Ft volt hazánkban.

Következtetés: A cukorbetegek szemészeti járó- és fekvőbeteg-ellátása alulfinanszírozott hazánkban. A proliferatív diabeteses retinopathia és a diabeteses maculaoedema növekvő társadalmi-gazdasági terhe miatt érdemes volna javítani a megelőzés, a szürés és a korai kezelés jelenlegi helyzetén.
\end{abstract}

Orv Hetil. 2021; 162(8): 298-305.

Kulcsszavak: költség, cukorbetegség, diabeteses retinopathia, szűrés

\section{Model-based economic burden of diabetic retinopathy in Hungary}

Introduction: Diabetic retinopathy affects every third people with diabetes mellitus in the world and is the leading cause of blindness in adults of working age.

Objective: The aim of this study was to analyse the economic burden associated with diabetic retinopathy in people aged 18 years and older in Hungary.

Method: Rapid assessment of avoidable blindness (RAAB) with the diabetic retinopathy module (DRM) based diabetic retinopathy cost model study was conducted in Hungary in 2018. Economic burden of diabetic retinopathy was analysed from the perspective of the National Health Insurance Fund system and the patients. Our prevalencebased diabetic retinopathy cost model was performed according to the Scottish diabetic retinopathy grading scale and based on the diabetic retinopathy severity stadium.

Results: The total diabetic retinopathy-associated economic burden was 43.66 billion HUF in 2018. The two major cost drivers were anti-VEGF injections (28.91 billion HUF) and vitrectomies (8.09 billion HUF) in Hungary; they covered to $84.7 \%$ of the total cost among people with diabetes mellitus. The diabetic retinopathy-related cost per patient was 54691 HUF in Hungary.

Conclusion: Outpatient and inpatient eye care of people with diabetes mellitus are underfinanced in Hungary. Due to the increasing socio-economic burden of proliferative diabetic retinopathy and diabetic macular oedema, it would be important to invest in proliferative diabetic retinopathy and macular oedema prevention, screening and early treatment.

Keywords: cost, diabetes mellitus, diabetic retinopathy, screening

Tóth G, Nagy ZZs, Németh J. [Model-based economic burden of diabetic retinopathy in Hungary]. Orv Hetil. $2021 ; 162(8): 298-305$.

(Beérkezett: 2020. augusztus 10; elfogadva: 2020. szeptember 17.) 


\section{Rövidítések}

$\mathrm{FLAG}=$ fluoreszcens angiográfia $; \mathrm{GDP}=$ (gross domestic product) bruttó hazai termék; HBCs = Homogén Betegségcsoportok; NEAK = Nemzeti Egészségbiztosítási Alapkezelo"; OCT $=$ optikaikoherencia-tomográfia $;$ OENO = Orvosi Eljárások Nemzetközi Osztályozása; $\mathrm{RAAB}=$ (rapid assessment of avoidable blindness) az elkerülhető vakság gyors felmérése; $\mathrm{DRM}=$ (diabetic retinopathy module $)$ diabeteses retinopathia modul; USA = (United States of America) Amerikai Egyesült Államok; VEGF = (vascular endothelial growth factor $)$ vascularis endothelialis növekedési faktor

A cukorbetegség és az annak szövődményeként kialakuló diabeteses retinopathia prevalenciája gyorsan nó világszerte [1]. Nincsenek pontos adataink az l-es és a 2 -es típusú cukorbetegség megoszlásáról, de az esetek 8590\%-át a 2-es típusú cukorbetegség teszi ki [2].

A cukorbetegek számát 2019-ben 463 millióra becsülték a világban, de számuk 2045-ig várhatóan el fogja érni a 700 millió fő́t [3]. A cukorbetegség előfordulási gyakorisága folyamatosan nő a populáció öregedése és a túlsúlyos emberek számának növekedése miatt [4]. Európában a cukorbetegséggel élő felnőttek számát 2019-ben 59 millióra becsülték, a betegség prevalenciája pedig $8,9 \%$ volt [3].

A cukorbetegek egyharmadának van valamilyen fokú diabeteses retinopathiája, és a diabeteses retinopathia felelős globálisan a vakság 1,0-4,8\%-ért $[5,6]$. Tizenöt évvel a cukorbetegség kialakulását követően a páciensek négyötöd részének van valamilyen fokú diabeteses maculaoedemája és/vagy diabeteses retinopathiája [7]. A diabeteses retinopathia a vakság egyik vezetô oka a középkorú lakosság körében a fejlett országokban [8]. 2010-ben a világban több mint 800 ezer, cukorbetegség miatt megvakult ember élt [9].

Különösen fontos a cukorbetegség és a diabeteses retinopathia epidemiológiai vonatkozásainak ismerete, hiszen például az USA-ban az egészségügyi kiadások egynegyede a cukorbetegséggel és annak szövődményeivel kapcsolatos kiadásokra fordítódik [10]. Magyarországon 2008-ban az 500 ezer cukorbeteg ellátására fordított egészségügyi kiadás a bruttó hazai termék (GDP) 0,65\%át tette ki [11].

A rendszeres időközönként elvégzett diabetológiai és szemészeti vizsgálatokkal és a diabeteses retinopathia időben való kezelésével a cukorbetegség következtében kialakuló látásromlás és vakság megelőzhetó lenne [12]. A sikeres megelőzés és az adekvát kezelés segítségével csökkenthetőkk lennének a kórképpel kapcsolatos egészségügyi kiadások is. A diabeteses retinopathiával kapcsolatos költségek ismerete kiemelt jelentőségú a diabeteses retinopathia egészségügyi költségvetésre kifejtett terhének volumene, illetve egy esetleges szúrőprogram bevezetésével várható nyereség tervezése miatt [13].

Néhány közlemény elérhető a nemzetközi szakirodalomban a diabeteses retinopathiával kapcsolatos költségekről, ezek a tanulmányok azonban a metodikai eltéré- sek miatt nehezen hasonlíthatók össze [13-17]. Emiatt alakítottuk ki a 'rapid assessment of avoidable blindness' (az elkerülhető vakság gyors felmérése; RAAB) alapú költségbecslő modellt [18], amelynek segítségével könynyen becsülhetôvé válik a diabeteses retinopathia költségterhe azon országokban, ahol korábban elvégezték a diabeteses retinopathia kiegészító modullal (DRM) együtt a RAAB-felmérést. A RAAB + DRM populációalapú felmérés megbízhatósága és validitása jól ismert, alapvetô célja a vakság előfordulási gyakoriságának és okainak, továbbá a cukorbetegség és a diabeteses retinopathia prevalenciájának meghatározása az 50 éves és annál idősebb korú lakosság körében [19-23].

Tanulmányunk célja a diabeteses retinopathia hazai költségterhének vizsgálata egy RAAB + DRM alapú költségbecslő modell segítségével.

\section{Módszer}

\section{Diabeteses retinopathia költségmodell}

A nemrégiben publikált, RAAB + DRM alapú diabeteses retinopathia költségmodell [18] segítségével prevalenciaalapú költségbecslést végeztünk. A költségbecslés során az 1 . ábrón látható skót diabeteses retinopathia klaszszifikációnak megfelelő diabeteses retinopathia súlyossági fokozatokat vettük alapul [24]. A diabeteses retinopathia kezelési modellt (1. táblázat) az 1 . ábrán ábrázolt súlyossági fokozatoknak és a hazai és nemzetközi diabeteses retinopathia irányelveknek megfelelően alakítottuk ki [16]. A tanulmány összhangban van a Helsinki Deklaráció elveivel.

A kontrollvizsgálatok gyakoriságát, az elvégzendő vizsgálatokat és a kezelés típusát a diabeteses retinopathia súlyossági fokozatától tettük függővé a modell kialakítása során. A diabeteses retinopathia nélküli cukorbetegeknélévenkénti ( $1 /$ bmodell), szemészetiszakrendelőben szakorvos által végzett kontrollvizsgálatot terveztünk. Az enyhe/obszerválandó diabeteses retinopathiás betegek egy naptári évben két alkalommal vesznek részt szemészeti ellenőrzésen (2. modell). A referálandó (szemészeti kezelést igénylő) nonproliferatív diabeteses retinopathiás páciensek esetében a rendszeres szemészeti kontrollokon kívül panretinalis lézerkezelés elvégzésére lehet szükség (3. modell). A proliferatív diabeteses retinopathiás pácienseknek a 3 . modellben megjelölteken kívül vitrectomiára lehet szükségük (4. modell). A referálandó diabeteses maculaoedemás betegeknek a rendszeres szemészeti utánkövetésen túl egy ülésben macularis lézerkezelésre és 3 alkalommal intravitrealis anti-VEGFinjekcióra lehet szükségük (5. modell). Anti-VEGF-injekció esetén felmerülő költségnél 1 ampulla ranibizumab (Lucentis $10 \mathrm{mg} / \mathrm{ml}$, Novartis Europharm, Dublin, Írország) fogyasztói árát és a kórházi beadás díját vettük alapul.

Költségmodellünk azzal az előfeltételezéssel készült, hogy minden diabeteses retinopathiás beteg csak a stan- 
1. táblázat | Diabeteses retinopathia költségmodell 2018-ban Magyarországon

\begin{tabular}{|c|c|c|c|c|}
\hline Költségmodell & Egység & $\begin{array}{l}\text { Aggregált költségek } \\
(\mathrm{Ft} / \text { év) }\end{array}$ & $\begin{array}{l}\text { Költségek költségelemek } \\
\text { szerinti bontásban (Ft/év) }\end{array}$ & Költségelemek \\
\hline $1 /$ a modell & /fó & 2500 & 2500 & 1) Éves szemészeti szưrés nonmydriaticus kamerával \\
\hline $\mathrm{l} / \mathrm{b}$ modell & /fö & 7993 & $\begin{array}{l}\text { 1) } \\
\text { 2) } 570 \\
5423\end{array}$ & $\begin{array}{l}\text { 1) Éves szemészeti vizsgálat szakrendelőben } \\
\text { 2) } 0,5 \text { kiesett munkanap }\end{array}$ \\
\hline 2. modell & /fó & 15986 & $\begin{array}{r}\text { 1) } 5140 \\
\text { 2) } 10846\end{array}$ & $\begin{array}{l}\text { 1) Félévenkénti szemészeti vizsgálat szakrendelőben } \\
\text { 2) } 2 \times 0,5 \text { kiesett munkanap }\end{array}$ \\
\hline 3. modell & /szem & 70882 & $\begin{array}{rr}\text { 1) } & 17990 \\
2) & 7269 \\
\text { 3) } & 37961 \\
4) & 2946 \\
5) & 4716\end{array}$ & $\begin{array}{l}\text { 1) Szemészeti vizsgálat szakrendelőben } 7 \text { alkalommal } \\
\text { (1. vizsgálat, } 3 \text { alkalom az ideghártya lézeres kezelése; } \\
3 \text { vizsgálat az utánkövetésre) } \\
\text { 2) Panretinalis lézerkezelés } 3 \text { ülésben } \\
\text { 3) } 7 \times 0,5 \text { kiesett munkanap } \\
\text { 4) } 1 \text { FLAG-vizsgálat } \\
\text { 5) } 2 \text { macula-OCT-vizsgálat }\end{array}$ \\
\hline 4. modell & /szem & 722080 & $\begin{array}{l}\text { 1) } 17990 \\
\text { 2) } 7269 \\
\text { 3) } 146421 \\
\text { 4) } 2946 \\
\text { 5) } \\
4716 \\
\text { 6) } \\
3738 \\
\text { 7) } 539000\end{array}$ & $\begin{array}{l}\text { 1) Szemészeti vizsgálat szakrendelóben } 7 \text { alkalommal } \\
\text { (1. vizsgálat; } 3 \text { alkalom az ideghártya lézeres kezelése; } \\
3 \text { vizsgálat az utánkövetésre) } \\
\text { 2) Panretinalis lézerkezelés } 3 \text { ülésben } \\
\text { 3) } 7 \times 0,5 \text { kiesett munkanap + } 10 \text { kiesett munkanap a vitrectomia } \\
\text { miatt } \\
\text { 4) } 1 \text { FLAG-vizsgálat } \\
\text { 5) } 2 \text { macula-OCT-vizsgálat } \\
\text { 6) } 2 \text { ultrahangvizsgálat } \\
\text { 7) } 1 \text { vitrectomia }\end{array}$ \\
\hline 5. modell & /szem & 1036082 & $\begin{array}{lr}\text { 1) } & 12850 \\
\text { 2) } & 2423 \\
\text { 3) } & 945594 \\
\text { 4) } & 70499 \\
\text { 5) } & 4716\end{array}$ & $\begin{array}{l}\text { 1) Szemészeti vizsgálat szakrendelőben } 5 \text { alkalommal } \\
\text { (1. vizsgálat; } 1 \text { alkalom az ideghártya lézeres kezelése; } \\
3 \text { vizsgálat az utánkövetésre) } \\
\text { 2) Macularis lézerkezelés } 1 \text { ülésben } \\
\text { 3) } 3 \text { intravitrealis anti-VEGF-injekció } \\
\text { 4) } 7 \times 0,5 \text { kiesett munkanap }+3 \text { kiesett munkanap az injekciók miatt } \\
\text { 5) } 2 \text { macula-OCT-vizsgálat }\end{array}$ \\
\hline
\end{tabular}

FLAG = fluoreszcens angiográfia; OCT $=$ optikaikoherencia-tomográfia; VEGF = vascularis endothelialis növekedési faktor

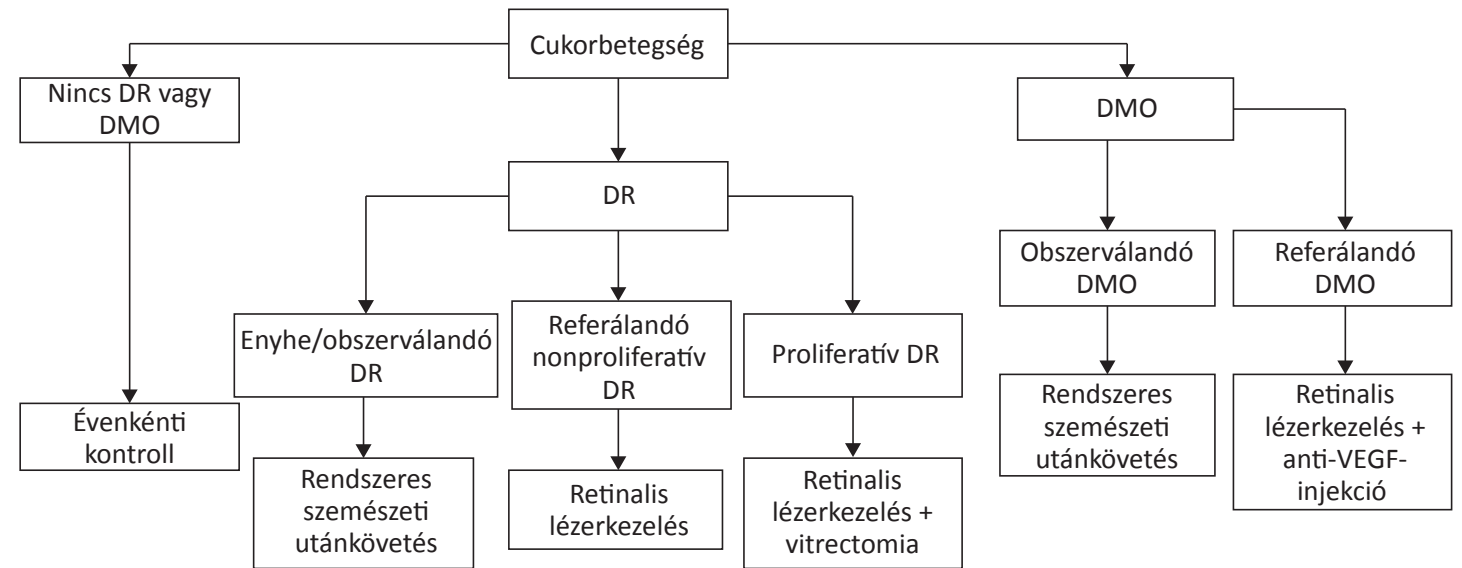

\begin{tabular}{l|l} 
1. ábra & $\begin{array}{l}\text { A diabeteses retinopathia kezelésének folyamata a skót diabeteses retinopathia klasszifikáció alapján } \\
\mathrm{DMO}=\text { diabeteses maculaoedema; } \mathrm{DR}=\text { diabeteses retinopathia; } \mathrm{VEGF}=\text { vascularis endothelialis növekedési faktor }\end{array}$
\end{tabular}

dard diabeteses retinopathiás kezelést kapja, és nem történik semmilyen komplikáció (például üvegtesti vérzés retinalis lézeres kezelés után vagy ideghártya-leválás vitrectomiát követően) (1. táblázat). A költségeknél vizsgáltuk az egészségügy és a páciens oldaláról felmerülő költségeket is (2. táblázat).
Az egészségügyi költségeknél kizárólag a Nemzeti Egészségbiztosítási Alapkezelő szemszögéből, járó- és fekvőbeteg-ellátásban felmerülő költségeket vizsgáltuk: általános szemészeti vizsgálat pupilla tágítását követően, optikaikoherencia-tomográfiás (OCT-), fluoreszcens angiográfiás (FLAG-) és ultrahangvizsgálat, ideghártya léze- 
A diabeteses retinopathiával kapcsolatban felmerülő költségelemek Magyarországon 2018-ban

\begin{tabular}{|c|c|c|c|}
\hline Költségelem & $\begin{array}{l}\text { OENO/HBCs } \\
\text { kód }\end{array}$ & Egység & $\begin{array}{c}\text { Egységköltség } \\
(\mathrm{Ft})\end{array}$ \\
\hline \multicolumn{4}{|l|}{ Egészségügyi költség } \\
\hline $\begin{array}{l}\text { Szürővizsgálat } \\
\text { nonmydriaticus } \\
\text { kamerával }\end{array}$ & $\begin{array}{l}\text { NEAK által } \\
\text { nem finanszí- } \\
\text { rozott }\end{array}$ & /fó & 2500 \\
\hline $\begin{array}{l}\text { Általános szemészeti } \\
\text { vizsgálat }\end{array}$ & $\begin{array}{ll}110 & 41 \\
12 & 130 \\
12 & 204\end{array}$ & /fö & 2570 \\
\hline Macula-OCT-vizsgálat & 12206 & /fö & 2358 \\
\hline FLAG-vizsgálat & 12221 & /fö & 2946 \\
\hline Ultrahangvizsgálat & 36113 & /fö & 1869 \\
\hline $\begin{array}{l}\text { Ideghártya lézeres } \\
\text { kezelése }\end{array}$ & 39110 & /alkalom & 2423 \\
\hline $\begin{array}{l}\text { Intravitrealis anti- } \\
\text { VEGF-injekció }\end{array}$ & $02 \mathrm{P} 0633$ & /szem & 315198 \\
\hline Vitrectomia & 02P 069B & /szem & 539000 \\
\hline \multicolumn{4}{|l|}{$\begin{array}{l}\text { A páciens oldaláról } \\
\text { felmerülő költség }\end{array}$} \\
\hline $\begin{array}{l}\text { A kiesett munkanapok } \\
\text { értéke }\end{array}$ & & /nap & 10846 \\
\hline
\end{tabular}

FLAG = fluoreszcens angiográfia $;$ HBCs = Homogén Betegségcsopor tok; NEAK = Nemzeti Egészségbiztosítási Alapkezelö; OCT = optikaikoherencia-tomográfia; OENO = Orvosi Eljárások Nemzetközi Osztályozása; VEGF = vascularis endothelialis növekedési faktor

res kezelése, intravitrealis anti-VEGF-injekció és vitrectomia. A páciensek oldaláról felmerülő költségeknél a kiesett munkanapok értékét vizsgáltuk, a magyarországi, 2018. évi átlagos bruttó napi kereset értékét alapul véve [25].

A járóbeteg-ellátáshoz társuló költségek vizsgálata az Orvosi Eljárások Nemzetközi Osztályozása kódrendszerben szereplő vizsgálati és beavatkozási tevékenységek listája és az egyes tételekhez tartozó pontértékek alapján történt, 2018-as forintértéken (1,98 Ft/német pont). A fekvőbeteg-ellátás költségeinek becslése a Homogén Betegségcsoportok (HBCs) finanszírozási rendszer alapján történt, 1 HBCs-súlyszám 2018-as forintértéke $198000 \mathrm{Ft}$.

Vitrectomiák esetében átlagosan 3 nap kórházi benntartózkodással és 7 nap, munkából való kieséssel számoltunk.

\section{Diabeteses retinopathia}

A cukorbetegség és a diabeteses retinopathia prevalenciajához a Tóth és mtsai $[19,26]$ által publikált epidemiológiai eredményeket vettük alapul (3. táblázat). A páciensek számát a Központi Statisztikai Hivatal által közölt, 2018. évi hazai népességszám alapján becsültük meg [27].

2018-ban 798,3 ezer felnőtt korú személynek volt cukorbetegsége Magyarországon. A diabeteses retinopa-
3. táblázat A cukorbetegség prevalenciája a 18 évnél idősebb és a diabeteses retinopathia prevalenciája az 50 évnél idősebb korú lakosság körében Magyarországon

\begin{tabular}{lcl}
\hline & Prevalencia (\%) & Irodalom \\
\hline Cukorbetegség & 9,9 & Tóth és mtsai [26] \\
\hline Nincs diabeteses retinopathia & 59,4 & \\
\hline $\begin{array}{l}\text { Valamilyen fokú diabeteses } \\
\text { retinopathia }\end{array}$ & 20,1 & Tóth és mtsai [19] \\
\hline Enyhe/obszerválandó NPDR & 16,3 & \\
\hline Referálandó NPDR & 1,4 \\
\hline Proliferatív DR & 1,4 \\
\hline Referálandó DMO & 3,5 \\
\hline
\end{tabular}

$\mathrm{DMO}=$ diabeteses maculaoedema $\mathrm{NPDR}=$ nonproliferatív diabeteses retinopathia

thia és a diabeteses maculaoedema prevalenciájáról csak az 50 évnél idősebb lakosság esetében áll rendelkezésünkre hazai epidemiológiai adat, ezért a 18 évnél idősebb korú populációra is ezeket az előfordulásigyakoriság-értékeket vettük alapul.

\section{Költség-haszon a diabeteses retinopathia nélküli cukorbetegek éves szürése esetén}

A diabeteses retinopathia költségterhét azzal az előfeltételezéssel állapítottuk meg, hogy minden, diabeteses retinopathia nélküli cukorbeteg évente legalább egyszer átesik pupillatágításos szemfenékvizsgálaton. Ezen kiegészítő analízis célja, hogy megállapítsuk, mekkora költséget takaríthatnánk meg az egészségügyi költségvetésnek abban az esetben, ha az összes, diabeteses retinopathia nélküli cukorbeteg az éves kontrollvizsgálat során nem szemészeti szakrendelőt, hanem egy nonmydriaticus funduskamerával felszerelt, telemedicinális szürőállomást keresne fel (1. táblázat, 1/a. modell). Nonmydriaticus kamerával végzett szűrővizsgálat esetében a kiesett munkaidő értéke elhanyagolható, hiszen az akár munkaidőn túl, hosszabb várakozás és pupillatágítás nélkül elvégezhető.

\section{Eredmények}

Hazánkban 2018-ban 798,3 ezer cukorbeteg volt, és 160,5 ezer páciensnek volt valamilyen fokú diabeteses retinopathiája (4. táblázat). Közülük 11,2 ezer fönek volt referálandó nonproliferatív, 11,2 ezernek proliferatív diabeteses retinopathiája és 27,9 ezernek referálandó diabeteses maculaoedemája $[19,26,27]$.

A teljes cukorbeteg populációban a cukorbetegek egyéves szemészeti ellátására vonatkozó költségteher 2018ban 43,66 milliárd Ft volt hazánkban (4. táblázat). Ez az érték magában foglalja a diabeteses retinopathia nélküli cukorbetegek éves szemészeti vizsgálatának költségét (3,79 milliárd Ft), az enyhe/obszerválandó nonpro- 
A diabeteses retinopathia költségterhe Magyarországon 2018-ban. A páciensek számát a Központi Statisztikai Hivatal által közölt, 2018. évi hazai népességszám alapján becsültük [27]

\begin{tabular}{|c|c|c|c|c|}
\hline & $\begin{array}{c}\text { Prevalencia } \\
(\%)\end{array}$ & $\begin{array}{c}\text { A páciensek száma } \\
\text { (ezer fó) }\end{array}$ & $\begin{array}{c}\text { Betegenkénti } \\
\text { költségteher }(\mathrm{Ft})\end{array}$ & $\begin{array}{l}\text { Összes költség } \\
\text { (milliárd Ft) }\end{array}$ \\
\hline & $2016^{\dagger}$ & 2018 & & 2018 \\
\hline Cukorbetegség & 9,9 & 798,3 & & \\
\hline Nincs diabeteses retinopathia & 59,4 & 474,2 & 7993 & 3,79 \\
\hline Valamilyen fokú diabeteses retinopathia & 20,1 & 160,5 & & \\
\hline Enyhe/obszerválandó diabeteses retinopathia & 16,3 & 130,1 & 15986 & 2,08 \\
\hline Referálandó nonproliferatív diabeteses retinopathia & 1,4 & 11,2 & 70882 & 0,79 \\
\hline Proliferatív diabeteses retinopathia & 1,4 & 11,2 & 722080 & 8,09 \\
\hline Referálandó diabeteses maculaoedema & 3,5 & 27,9 & 1036082 & 28,91 \\
\hline Összesen & & & & 43,66 \\
\hline
\end{tabular}

†Tóth és mtsai $[19,26]$

liferatív (2,08 milliárd Ft), a referálandó nonproliferatív $(0,79$ milliárd $\mathrm{Ft})$, a proliferatív diabeteses retinopathiásoknak $(8,09$ milliárd $\mathrm{Ft})$ és a referálandó diabeteses maculaoedemás pácienseknek $(28,91$ milliárd $\mathrm{Ft})$ a diabeteses retinopathia súlyossági fokának megfelelő modellben jelölt standard kezelési költségét. A teljes cukorbeteg populációban az egy páciensre jutó átlagos költségteher (beleértve a diabeteses retinopathia nélküli cukorbetegek éves vizsgálatát is) 54 691 Ft volt hazánkban 2018-ban.

\section{Költség-haszon a diabeteses retinopathia nélküli cukorbetegek szüröpizsgálatában}

A diabeteses retinopathia nélküli cukorbetegek éves szemészeti vizsgálatának költségterhe 2018-ban 3,79 milliárd Ft volt, amennyiben a vizsgálatot szakrendelőben szemész szakorvos végezte el, és 1,19 milliárd Ft, amenynyiben ugyanez telemedicinális szűrőrendszer segítségével történt volna meg.

\section{Megbeszélés}

Tudomásunk szerint ez az első magyar nyelvü, RAABalapú tanulmány, amely a cukorbetegség szemészeti szövődményeinek költségterhét vizsgálja Magyarországon. A cukorbetegek száma 2018-ban 798,3 ezer före volt tehető hazánkban, akik közül 160,5 ezer főnek volt valamilyen fokú diabeteses retinopathiája. Számításaink alapján a cukorbetegség szemészeti szövődményei kapcsán felmerülő összes költség 2018-ban 43,66 milliárd Ft volt. 2018-ban az állami egészségügyi kiadások 4,7\%-os GDP-aránya mellett az állami egészségügyi kiadások 2,18\%-a fordítódott diabeteses retinopathiával kapcsolatban felmerülő költségekre [28].

A legfőbb költségviselők a hazai cukorbetegek szemészeti ellátásában, a 2018-as évet vizsgálva, az intravitrealis anti-VEGF-injekciók és a vitrectomiák voltak. Ez a két kezelési mód volt felelős a diabeteses retinopathia kap- csán felmerülő összes költség 84,7\%-áért. A diabeteses retinopathia megelőzésével vagy megfelelő időben való kezelésével ennek az összegnek a legnagyobb része megtakarítható volna. A diabeteses retinopathia következtében kialakuló látásromlás kellően megszervezett szűrőprogrammal, a legalább évenként ténylegesen elvégzett szemészeti vizsgálatokkal és a megfelelő időben elvégzett szemészeti kezelések segítségével 90\%-kal csökkenthető volna [29]. Ezenfelül a látásromlás következtében kialakuló termelékenységvesztés értéke is visszatérülne, amely a közvetlen egészségügyi kiadások több mint ötszörösére tehető [30].

Németországban [14] a diabeteses retinopathia kapcsán felmerülő összes költséget 3,51 milliárd USD-re becsülték 8 millió cukorbetegre vonatkozóan 2002-ben. Az egy diabeteses retinopathiás páciensre jutó költségteher lényegesen magasabb volt (389-2543 USD) az USA-ban [15], Svájcban [31] és Németországban [14] az ezredforduló környékén, és 2014-ben Szingapúrban [13], mint hazánkban (198 USD). A különböző tanulmányok összehasonlítása nemcsak az eltérő metodológiai megközelítések miatt nehézkes, hanem amiatt is, hogy 2011-tôl megjelentek a diabeteses maculaoedema kezelésében a különböző intravitrealis anti-VEGF-készítmények, amelyek jelentős drágulást idéztek elő a diabeteses retinopathia kezelésében, mivel jelentősen megnőtt azok jelentősége és alkalmazási gyakorisága a macularis lézerkezelésésekhez képest [17].

A költségelemek más országokból közölt adatokkal való összehasonlítása is jól mutatja a hazai cukorbetegek járó- és fekvőbeteg-ellátásának alulfinanszírozottságát. Csupán a németországi adatok összehasonlításával is jól látható ez a tendencia. Németországban egy OCT-vizsgálat esetén 6,5×, FLAG-nál 5,7×, de egy ultrahangvizsgálatnál is $2 \times$ annyit fizet az egészségügyi biztosító az elvégzett szolgáltatásért, mint hazánkban [32, 33].

A hazai, egy páciensre jutó átlagos költségteher az Indonéziából publikált értéknél is lényegesen alacsonyabb, ez a különbség azonban félrevezető lehet, ugyanis a dia- 
beteses retinopathia előfordulási gyakorisága Indonéziában több mint a kétszerese a hazai prevalenciának [16].

Hazánkban megközelítóleg 1000 ember vakul meg évente a diabeteses retinopathia késői felismerése és kezelése miatt [34]. Ismert, és becslésünkből is jól látszik, hogy a diabeteses retinopathia súlyossága jól korrelál a közvetlen egészségügyi költségek nagyságával [13], és a cukorbetegséghez kapcsolódó közvetlen költségek meghaladják a közvetett költségek nagyságát [35]. A korábbi felmérésekhez hasonlóan, a mi tanulmányunkban is a proliferatív diabeteses retinopathia és a diabeteses maculaoedema jelentette a legnagyobb költségterhet a diabeteses retinopathia kezelésében [16]. A cukorbetegség okozta súlyos látásvesztés elkerülhető volna, illetve a vitrectomiák és anti-VEGF-injekciók okozta költségteher csökkenthető volna a nemzeti irányelvek által előírt, megfelelő gyakoriságú szemészeti vizsgálatok és az esetlegesen szükséges retinalis lézerkezelések megfelelő időben való elvégzésével, hiszen azok lényegesen olcsóbbak a vitrectomiánál vagy az intravitrealis injekcióknál.

Korábbi felmérésünkből [19] láthattuk, hogy az ismert cukorbetegek alig fele és a látást veszélyeztető diabeteses retinopathiás páciensek csupán 60\%-a esik át a hazai szakmai irányelvek által kötelező minimumként megjelölt évenkénti szemfenékvizsgálaton. Hovatovább, hazánkban az ismert cukorbetegek egyharmada még sohasem esett át szemfenékvizsgálaton [19]. Hazai környezetben egy telemedicinális szürőprogram (hordozható nonmydriaticus kamera és kiértékelő központ) segítségével olcsóbban elvégezhető volna a diabeteses retinopathia nélküli cukorbetegek éves vizsgálata, mint szemész szakorvosnál szemészeti szakrendelőben, mivel egy szűrőprogram esetében a várakozási idő kiesik, illetve pupillatágítás nélkül, akár a munkaidőn túl is elvégezhető volna az éves szemfenékvizsgálat. Ismert, hogy a nonmydriaticus funduskamerákkal megfelelően végzett diabeteses retinopathia szúrés szenzitivitása meghaladja a 92\%-ot, specificitása pedig a 97\%-ot [36]. Esetleges szemfenéki szövődmény megléte esetén pedig ezen betegek a felszabadult szemészorvosi kapacitás miatt feltehetőleg rövidebb előjegyzési és várakozási időt követően kerülhetnének be a szakorvosi ellátásba. Egy országos telemedicinális szúrőprogram bevezetésével hazánkban a szemész szakorvosok tehermentesítése mellett 2,60 milliárd Ft-ot lehetett volna megspórolni az egészségügyi kiadásokból 2018-ban, amennyiben csupán a diabeteses retinopathia nélküli cukorbetegeket nem szemészeti szakrendelőben, hanem szûrőállomásokon vizsgáltuk volna. Ismert továbbá, hogy szûrôprogramok bevezetésével javítani lehet a beteg-együttmúködést is, mivel így elkerülhetôvé válnak a várakozási idővel és a pupillatágítással járó kellemetlenségek, és a páciensek közvetlenül a vizsgálat után megtekinthetik a saját szemükról készült felvételeket [37, 38].

Tanulmányunk korlátai közé tartoznak a következők: a diabeteses retinopathia és a diabeteses maculaoedema előfordulási gyakorisága csak az 50 év feletti személyek körében ismert hazánkban, ezért ezeket a prevalenciaadatokat extrapoláltuk a teljes felnőttkorú lakosságra. Ez a diabeteses retinopathia és a diabeteses maculaoedema prevalenciaadatainak alul- vagy túlbecsléséhez vezethetett. A pontatlanság valószínúségét csökkenti azonban, hogy a 18 és 49 év közötti korú cukorbetegek aránya a teljes felnőtt korú cukorbeteg népességben 10,1\% [39]. A fiatalabb korcsoportok körében azonban magasabb az 1-es típusú cukorbetegség előfordulási gyakorisága a 2-es típusúéhoz képest [40], és az 1-es típusú cukorbetegekben a diabeteses retinopathia prevalenciája jóval magasabb a 2-es típusúakhoz képest, elérheti akár az 56\%-ot [41]. Mivel incidenciaadatok nem állnak rendelkezésünkre a cukorbetegség és a diabeteses retinopathia vonatkozásában, költségelemzésünkben a 2016-ban publikált prevalenciaadatokat használtuk [19, 26]. Becsléseinket azzal az előfeltételezéssel végeztük, hogy minden páciensnek csak az egyik szeme esik át a hazai diabeteses retinopathia irányelv által javasolt alapkezelésen, anélkül hogy bármilyen kiegészítő kezelést végeznénk (például többszöri vitrectomia, intravitrealis szteroidinjekció).

\section{Következtetés}

Következtetésül elmondhatjuk, hogy a cukorbetegek szemészeti járó- és fekvőbeteg-ellátása alulfinanszírozott hazánkban, és az egy cukorbetegre jutó átlagos szemészeti költségteher alacsonyabb más országokhoz képest. A proliferatív diabeteses retinopathia és a cukorbetegség következtében kialakuló vakság növekvő gazdasási és társadalmi terhe miatt érdemes volna országos szürőprogram indításába és a diabeteses retinopathia prevenciójának erősítésébe invesztálni.

Anyagi támogatás: Készült „Az orvos-, egészségtudományi- és gyógyszerészképzés tudományos múhelyeinek fejlesztése" címú projekt támogatásával (azonosítószám: EFOP-3.6.3-VEKOP-16-2017-00009; Dr. Tóth Gábor). A támogatónak nem volt szerepe a kézirat megtervezésében vagy megírásában.

Szerzôi munkamegosztás: T. G.: A vizsgálat megtervezése, lefolytatása és a kézirat megírása. N. Z. Zs., N. J.: A kézirat megszövegezése és javítása. A cikk végleges változatát valamennyi szerző elolvasta és jóváhagyta.

Érdekeltségek: A szerzőknek nincsenek érdekeltségeik. 


\section{Irodalom}

[1] Shaw JE, Sicree RA, Zimmet PZ. Global estimates of the prevalence of diabetes for 2010 and 2030. Diabetes Res Clin Pract. 2010; 87: 4-14.

[2] Sztanek F, Jebelovszki É, Gaszner B, et al. Diagnosis of diabetic cardiac autonomic neuropathy. [A diabeteses cardialis autonóm neuropathia diagnosztikája.] Orv Hetil. 2019; 160: 1366-1375. [Hungarian]

[3] International Diabetes Federation. IDF Diabetes Atlas. 9th edn IDF Excutive Office, Brussels, 2019. Available from: http:// www.diabetesatlas.org [accessed: 25 February 2020].

[4] Tóth G, Szabó D, Sándor GL, et al. Rural-urban disparities in the prevalence of diabetes and diabetic eye complications in Hungary. Spektrum Augenheilkd. 2019. Doi: 10.1007/s00717019-00433-6.

[5] Resnikoff S, Pascolini D, Mariotti SP, et al. Global magnitude of visual impairment caused by uncorrected refractive errors in 2004. Bull World Health Organ. 2008; 86: 63-70.

[6] Pascolini D, Mariotti SP. Global estimates of visual impairment: 2010. Br J Ophthalmol. 2012; 96: 614-618.

[7] Czakó C, Sándor GL, Ecsedy M, et al. Evaluation of diabetic microangiopathy using optical coherence tomography angiography. [Diabeteses kisér-károsodás vizsgálata optikai koherencia tomográfián alapuló angiográfiával.] Orv Hetil. 2018; 159: 320_326. [Hungarian]

[8] World Health Organization. World report on vision. Geneva, 2019. Licence: CC BY-NC-SA 3.1 IGO.

[9] Leasher JL, Bourne RR, Flaxman SR, et al. Erratum. Global estimates on the number of people blind or visually impaired by diabetic retinopathy: a meta-analysis from 1990 to 2010. Diabetes Care 2016; 39: 1643-1649; 2096.

[10] Hogan P, Dall T, Nikolov P, American Diabetes Association. Economic costs of diabetes in the US in 2002. Diabetes Care 2003; 26: 917-932.

[11] Vokó Z, Nagyjánosi L, Kaló Z. Direct health care costs of diabetes mellitus in Hungary. [A cukorbetegség közvetlen egészségügyi költségei Magyarországon.] Lege Artis Med. 2009; 19: 775780. [Hungarian]

[12] Yau JW, Rogers SL, Kawasaki R, et al. Global prevalence and major risk factors of diabetic retinopathy. Diabetes Care 2012; 35: 556-564.

[13] Zhang X, Low S, Kumari N, et al. Direct medical cost associated with diabetic retinopathy severity in type 2 diabetes in Singapore. PLOS ONE 2017; 12: e0180949.

[14] Happich M, Reitberger U, Breitscheidel L, et al. The economic burden of diabetic retinopathy in Germany in 2002. Graefe's Arch Clin Exp Ophthalmol. 2008; 246: 151-159.

[15] Schmier JK, Covert DW, Lau EC, et al. Medicare expenditures associated with diabetes and diabetic retinopathy. Retina 2009; 29: 199-206

[16] Sasongko MB, Wardhana FS, Febryanto GA, et al. The estimated healthcare cost of diabetic retinopathy in Indonesia and its projection for 2025. Br J Ophthalmol. 2020; 104:487-492.

[17] Romero-Aroca P, de la Riva-Fernandez S, Valls-Mateu A, et al. Cost of diabetic retinopathy and macular oedema in a population, an eight year follow up. BMC Ophthalmol. 2016; 16: 136.

[18] Tóth G, Limburg H, Szabó D, et al. Rapid assessment of avoidable blindness-based healthcare costs of diabetic retinopathy in Hungary and its projection for the year 2045. Br J Ophthalmol. Published Online First: 11 August 2020. Doi: 10.1136/bjophthalmol-2020-316337.

[19] Tóth G, Szabó D, Sándor GL, et al. Diabetes and diabetic retinopathy in people aged 50 years and older in Hungary. Br J Ophthalmol. 2017; 101: 965-969.

[20] Szabó D, Sándor GL, Tóth G, et al. Visual impairment and blindness in Hungary. Acta Ophthalmol. 2018; 96: 168-173.
[21] Tóth G, Szabó D, Sándor GL, et al. Regional disparities in the prevalence of diabetes and diabetic retinopathy in Hungary in people aged 50 years and older. [Cukorbetegség és retinopathia diabetica regionális egyenlőtlenségei Magyarországon az 50 éves és idősebb korú lakosság körében.] Orv Hetil. 2017; 158: 362367. [Hungarian]

[22] Tóth G, Szabó D, Sándor GL, et al. Diabetes and diabetic retinopathy: RAAB + DRM survey from Hungary. [A cukorbetegség és a diabeteses retinopathia hazánkban a RAAB + DRM-vizsgálat eredményei szerint.] Szemészet 2018; 155: 82-89. [Hungarian]

[23] Szabó D, Tóth G, Sándor GL, et al. Causes of blindness in Hungary - conducting the first RAAB study in Hungary. [A vakság okai Magyarországon. A RAAB-metodika első hazai megvalósítása.] Szemészet 2017; 154: 119-125. [Hungarian]

[24] Scottish Diabetic Retinopathy Screening Collaborative. Available from: http://www.ndrs.scot.nhs.uk/ClinGrp/Docs/Grading Scheme 2007 v1.1.pdf/ [accessed: 04. 07. 2020].

[25] Hungarian Central Statistical Office. Average earnings, Decem ber, 2018, [Központi Statisztikai Hivatal. Átlagkereset, 2018 december.] KSH, Budapest. Available from: https://www.ksh. hu/docs/hun/xftp/gyor/ker/kerl812.html [accessed: 22. 06. 2020]. [Hungarian]

[26] Tóth G, Szabó D, Sándor GL, et al. Diabetes and blindness in people with diabetes in Hungary. Eur J Ophthalmol. 2019; 29: 141-147.

[27] Hungarian Central Statistical Office. Number of population in Hungary by gender and age, Januaryl, 2020. [Központi Statisztikai Hivatal. Magyarország népességének száma nemek és életkor szerint. 2020. január 1.] KSH, Budapest. Available from: https://www.ksh.hu/interaktiv/korfak/orszag.html [accessed: 20. 06. 2020]. [Hungarian]

[28] Hungarian Central Statistical Office. Health expenditure in the percent of GDP (2003-2010) in Hungary. [Központi Statisztikai Hivatal. Egészségügyi kiadások alrendszerenként, a GDP \%-ában, egészségügyi beruházási ráfordítás (2003-2010.)] KSH, Budapest. Available from: https://www.ksh.hu/docs/hun/ xstadat/xstadat_eves/i_fec001b.html [accessed: 22. 06. 2020]. [Hungarian]

[29] Khan T, Bertram MY, Jina R, et al. Preventing diabetes blindness: cost effectiveness of a screening programme using digital non-mydriatic fundus photographyfor diabetic retinopathy in a primary health care setting in South Africa. Diabetes Res Clin Pract. 2013; 101: 170-176.

[30] Scanlon PH. The English National Screening Programme for diabetic retinopathy 2003-2016. Acta Diabetol. 2017; 54: 515525.

[31] Schmitt-Koopmann I, Schwenkglenks M, Spinas GA, et al. Direct medical costs of type 2 diabetes and its complications in Switzerland. Eur J Public Health 2004; 14: 3-9.

[32] DRG Research Group. Available from: https://www.drg-research-group.de/ [accessed: 16. 06. 2020]. [German]

[33] Kassenärztliche Bundesvereinigung. Available from: www.kbv.de [accessed: 16. 06. 2020]. [German]

[34] Németh J, Frigyik A, Vastag O, et al. Causes of blindness in Hungary between 1996 and 2000. [Vaksági okok Magyarországon 1996 és 2000 között.] Szemészet 2005; 142: 126-132. [Hungarian]

[35] Brodszky V, Péntek M, Jelics N, et al. Cost of illness of adult diabetic patients treated with insulin. A cross-sectional survey of 480 consecutive patients with type 1 and type 2 diabetes cared in general practitioner's practices or in outpatients settings. [Inzulinnal kezelt felnőttkorú cukorbetegek egészségügyi költségterhe. Felmérés háziorvosi praxisokban, illetve szakellátóhelyeken gondozott 480 beteg keresztmetszeti vizsgálata alapján.] Diabetol Hung. 2010; 19: 37-44. [Hungarian]

[36] Aptel F, Denis P, Rouberol F, et al. Screening of diabetic retinopathy: effect of field number and mydriasis on sensitivity and 
specificity of digital fundus photography. Diabetes Metab. 2008; 34: 290-293.

[37] Eszes DJ, Szabó DJ, Russell G, et al. Diabetic retinopathy screening using telemedicine tools: pilot study in Hungary. J Diabetes Res. 2016; 2016: 4529824

[38] Németh J, Maka E, Szabó D, et al. Operating telemedicine ophthalmic screening programs and their possibilities in Hungary. [Múködő telemedicinális szemészeti szúróprogramok és lehetőségek hazánkban]. IME 2019; 18: 46-51. [Hungarian]

[39] Domján BA, Ferencz V, Tänczer T, et al. Large increase in the prevalence of self-reported diabetes based on a nationally representative survey in Hungary. Prim Care Diabetes 2017; 11: 107111 .
[40] Maahs DM, West NA, Lawrence JM, et al. Epidemiology of type 1 diabetes. Endrocrinol Metab Clin North Am. 2010; 39: 487497.

[41] Lee R, Wong TY, Sabanayagam C. Epidemiology of diabetic retinopathy, diabetic macular edema and related vision loss. Eye and Vision 2015; 2: 17.

(Tóth Gábor dr., Budapest, Üllői út 26., 1085 e-mail: gabortothgabor@gmail.com)

\section{Pályázati felhívás}

Dr. Fehér János professzornak, a Semmelweis Egyetem II. sz. Belgyógyászati Klinikája volt igazgatójának, az Orvosi Hetilap volt föszerkesztőjének emlékére 2011-ben alapítvány létesült.

A Dr. Fehér János Emlékére Alapítvány fő célja a belgyógyászat, különösen a hepatológia szabad gyökös és immunológiai vonatkozású témaköreinek kutatása, fejlesztése, támogatása, illetve ösztönzése oly módon, hogy az alapítvány kamatából fiatal egyetemi oktatók, PhD-hallgatók és orvostanhallgatók részesüljenek.

A pályázatok benyújtásának határideje: 2021. április 15.

A dolgozatot „Dr. Fehér János pályázat” megjelöléssel kell benyújtani, és a pályázathoz mellékelni kell a pályázó önéletrajzát is.

A dolgozatot a Dr. Fehér János Emlékére Alapítvány Kuratóriuma elnökének

(Dr. Hagymási Krisztina) vagy titkárának (Dr. Lengyel Gabriella) kell eljuttatni.

Beküldési cím: Semmelweis Egyetem, I. Sebészeti és Intervenciós Gasztroenterológiai Klinika 1082 Budapest, Üllői út 78.

A díj odaítéléséről a kuratórium dönt. A díj átadására az Orvosi Hetilap Markusovszky-ünnepségén kerül sor, ahol a nyertes pályázó 5 perces előadásban foglalhatja össze az eredményeit.

A cikk a Creative Commons Attribution 4.0 International License (https://creativecommons.org/licenses/by/4.0/) feltételei szerint publikált Open Access közlemény, melynek szellemében a cikk bármilyen médiumban szabadon felhasználható, megosztható és újraközölhető, feltéve, hogy az eredeti szerző és a közlés helye, illetve a CC License linkje és az esetlegesen végrehajtott módosítások feltüntetésre kerülnek. (SID_1) 